\title{
THE TRAINING OF BIOCHEMISTS
}

$\mathrm{U}$ NTIL comparatively recently most biochemists in Great Britain had received their early training in other disciplines such as chemistry, physiology or medicine. However, the rapid progress of biochemistry during the post-wax period has been paralleled by an increase in the number of biochemistry departments within British universities, and it is likely that most of our future research biochemists will graduate from these departments, having followed courses leading to the honours B.Sc. degree.

It is probably true to say that no one is yet certain, to the point of dogmatism, as to the best way of training such biochemists, and this no doubt reflects the position of biochemistry as a 'meeting-point' of so many other disciplines. In order to create discussion and thought on this topic the Biochemical Society held, during the afternoon of July 13, a colloquium on "The Training of Biochemists". The colloquium, which formed part of the four-hundred and eighth meeting of the Society, was held in Oxford under the chairmanship of Dr. K. S. Dodgson and was attended by more than 250 members and guests.

One of the principal controversies of the proceedings centred around the contributions of the first two speakers. Prof. S. V. Perry outlined the growth and development of biochemistry in Britain and stressed the velue of the three- or four-year B.Sc. honours course in the training of the biochemist. Such courses were now firmly established in their own right and provided not only an intellectual challenge but also a sound basis for education in its broader sense. In contrast, Prof. B. Spencer suggested that biochemistry was more fitted to be a postgraduate subject, and illustrated his point with detailed reference to the systems in use in most American universities. Some lively discussion followed these contributions and although the weight of opinion was perhaps loaded in favour of the undergraduate course it was clear that most people, recognizing the important links between biochemistry and other disciplines, felt that other pathways by which biochemists emerged should remain open. Prof. R. A. Morton reiterated from the floor that the educational aspects of a university course should not be neglected in favour of 'training'. Biochemistry as an undergraduate subject was intellectually stimulating, and courses should always include aspects hard enough to stretch the mind of the student. What matters is the spirit of the course rather than the factual content.

The views of industry regarding the training of biochemists were outlined by Dr. W. F. J. Cuthbertson, who pointed out that industry as a whole was still not fully aware of the potential value of the trained biochemist. He suggested that a group should be formed, composed of representatives from academic life, industry and the various industrial research associations, to determine the contribution that biochemical graduates could make in industry, their present level of employment and the possible future requirements for them. In noting the differences between research in industry and in universities or research institutes, Dr. Cuthbertson suggested that industrial research was in some ways more exciting and variable. The freedom of academic research was sometimes illusory, and the academic research worker soon realizes that certain projects and methods of approach are more likely than others to attract financial aid to research. Most large industrial concerns exhibit a liberal attitude towards research, and the industrial biochemist is usually free to work on anything he choses providing that he can persuade his authorities to supply the necessary facilities. The training that was appropriate to the industrial biochemist was not markedly different from that followed by most university departments, but additional attention might be given to special facets such as microbiology and the use of statistics. The ability to present an account of his work in unambiguous simple Fnglish was perhaps even more important for the industrial biochemist than for his academic friends, because many of his findings may have to be assessed by people with little or no training in his own discipline or, for that matter, in any other scientific subject.

After some preliminary sparring with questioners, Dr. Cuthbertson was challenged outright as to whether industry was satisfied with its biochemical recruits. In reply he said that, generally speaking, expanding university departments and research institutes were skimming the cream of the graduates and a more encouraging attitude to industry from within university departments would be welcomed. Several speakers suggested that industry was perhaps responsible for any unfavourable attitude which might exist and, in particular, the use of graduates as 'superior technicians' by industry was deprecated. This unwelcome development certainly appears to be on the increase, and reflects the present shortage of trained technical assistants-a situation which technical colleges in Britain should be given every encouragement to ameliorate.

University and departmental entrance requirements were discussed by Dr. Margaret Kerly, and the meeting was greatly indebted to her for the work she had done in collating so much diverse and scattered information. In biochemistry, perhaps more than any other subject, opinions as to the school background appropriate to students vary considerably. Dr. Kerly pointed out that the number of sixth-form students from any one school who were interested in a biochemical career varied from none to 2 or 3 only, and it was therefore unrealistic to expect schools to modify time-tables in order to cater for potential biochemists. Time-table problems usually resulted in sixth-formers taking chemistry, physics and mathematics for advanced level General Certificate of Education, in which case they were weak on the biological side, or alternatively, chemistry, physics or mathematics and a biological subject, in which case they tended to be weak in either physics or mathematics. A possible solution might be the introduction of a new advanced level subject which combined those sections of the present physics and mathematies courses which are most necessary for all biologists.

In spite of the Biochemical Society's recent pamphlet, Careers in Biochemistry, inquiries in schools had convinced Dr. Kerly that many science masters and sixth-form students were only vaguely aware of the potentialities of a career in biochemistry. More propaganda will be needed in schools if more good candidates for biochemistry are to be fortheoming. Further support for this contention came during 
discussion, and it was suggested that individual departments could and should do more in this respect, particularly in the light of the shortage of biochemists which Britain is now experiencing.

In describing the recently revised four-year biochemistry course at Oxford, Prof. D. D. Woods stressed the importance of adequate background teaching, particularly in chemistry, but pointed out the need to introduce biochemistry at an early stage in the course in order to stimulate student interest. Experimentation in biochemical research is steadily becoming more sophisticated, and recent trends have emphasized the more biological aspects of the subject. The early introduction of such topics as cell physiology and genetics is therefore an important feature of the course at Oxford, and the Biochemistry Department was particularly fortunate in having the co-operation of other departments in the teaching of such topics.

Much interest was expressed in the course at Oxford, particularly from the point of view of its breadth of outlook, although it was clear that Oxford with its resources was in a particularly favourable position to overcome time-table problems which so beset smalier departments.

In the final paper, Dr. E. M. Crook discussed the M.Sc. course in biochemistry which has been in existence for some years at University College, London. Dr. Crook suggested that a good deal can be said for not attempting to teach biochemistry as an undergraduate subject, but a major disadvantage in adopting this attitude, so far as the course at University College, London, had been concerned, was that few M.Sc. candidates have learned any biochemistry, even of the most elementary kind, before entering the course. Moreover, a first-class honours graduate in, for example, chemistry has to be exceptionally strong-minded to proceed to an M.Sc. course in another subject in the face of the psychological impulse to go on at once to prove himself as a research worker. The danger, therefore, is that the M.Sc. course may tend to attract the less-able student who may look on the course as a means of 'upgrading' a relatively poor initial degree. On the whole, however, it seems likely that postgraduate teaching must increase. Various departments could, between them, provide a formidable series of postgraduate courses of different specialist nature, and this could prove of great value in strengthening the subject in Britain.

In summarizing the proceedings, Prof. F. C. Happold confessed himself to be out of sympathy with the title of the colloquium. We were not concerned with the training of biochemists as one trains circus animals but with their education. The latter embraces the former but it is also more difficult to achieve. In any event, those departments which already had honours courses in biochemistry were certainly not proposing to abandon them. Such courses were an excellent education in themselves providing that sufficient time was available to do the job properly. In his own opinion the four-year course appeared to be particularly satisfactory from this point of view.

Judging from the conversations which followed the closing of the meeting, the original aims of the colloquium in stimulating thought and discussion had been successfully achieved. The Biochemical Society hopes to publish the proceedings of the meeting, in monograph form, at an early date.

K. S. DoDgson

\section{NEWS and VIEWS}

New President of the British Association : Sir John Cockcroft, O.M., K.C.B., C.B.E., F.R.S.

Srr John Cockcroft, Master of Churchill College, Cambridge, and part-time member of the U.K. Atomic Energy Authority, has been elected president for 1962 of the British Association for the Advancement of Science. That year, the annual meeting will be held in Manchester.

As is well known, Sir John has achieved world-wide fame as an atomic physicist. He was Jacksonian professor of natural philosophy in the University of Cambridge during 1939-46. His first researches, beginning in 1924 at Cambridge, were concerned with the heating of transformer coils, and later, at the Cavendish Laboratory, he carried out work on the deposition of surface films by atomic beams. Later, with Kapitza, he designed much of the equipment used in the production of intense magnetic fields. In 1932, with Walton, he had devised the arrangement by which nuclear disintegration by artificially accelerated particles was first observed. He was a prime mover in the development of equipment and the erection of buildings for which the physicists at Cambridge must now be grateful. During most of the Second World War period he was chief superintendent of air defence, Research and Development Establishment, Ministry of Supply, and then became director of the Atomic Energy Division, National Research Council of Canada, during 1944-46. $\mathrm{He}$ was then appointed director of the Atomic Energy Research Establishment at Harwell.

Such is the high esteem in which his work is held that Sir John has been or is a member of many scientific and advisory organizations and he has been the recipient of numerous State, academic and other honours. Among the most recent are the 1961 Atoms for Peace Award, which was established as a memorial to Henry Ford and his son Edsel, consisting of a gold medal and 75,000 dollars, and the chancellorship of the Australian National University, Canberra.

\section{Norwich and its Region}

Visitors to Norwich will find Norwich and its Region a very pleasing work. (Pp. 224. Norwich: Local Executive Committee of the British Association for the Advancement of Science, 1961. 158.). It provides a most informative survey of the region of Norfolk and north Suffolk. The survey opens with a concise account of the historical events which have moulded East Anglia. To-day it is in the midst of a second industrial and agricultural revolution. Though to some it may appear a quiet backwater, residents are conscious of the mounting pace at which it is being drawn relentlessly into the main stream. The second section deals with geology, physiographical features, climate, and the nature of the soil. Results of recent research are emphasized. In fact, advances in knowledge of the Pleistocene deposits have been 